\title{
On the Making of Sense in Sensemaking: Decentred Sensemaking in the Meshwork of Life
}

Organization Studies

(c) The Author(s) 2018 Reprints and permissions: sagepub.co.uk/journalsPermissions.nav DOI: $10.1177 / 0170840618765579$ www.egosnet.org/os @SAGE

\section{Lucas D. Introna}

Lancaster University Management School, UK

\begin{abstract}
This paper proposes and argues for sensemaking practices as fundamentally decentred. Sensemaking has been, at least since the late 1980s, an enduring subject for organisation studies researchers, and much longer for organisational practitioners. This research tradition has, however, tended to have a particular understanding of temporality (as divisible), tended to be centred on the human sense-makers, and privileged as more valid that which can be made present, through deliberative sensemaking practices, at the expense of that which is absent, and perhaps ineffable. In short, by locating sensemaking in the deliberative sensemaking practices of humans other significant constitutive conditions of sensemaking became obscured from view. The main thrust of the paper is to develop a notion of sensemaking that is decentred - not simply at the disposal of human subjects - and where sense is always and already given and made simultaneously. That is, where every human attempt at framing is itself already enframed, significantly. We show how this reimagining of sensemaking, as decentred, has the potential to open up new avenues of research in sensemaking practices - avenues that are more sensitive to temporal flow, the more-than-human, immanence, and the precarity of such practices. This shift is significant theoretically but also practically.
\end{abstract}

\section{Keywords}

Bergson, flow, Heidegger, Ingold, Mann Gulch, mood, sensemaking, temporality

\section{Introduction}

Order, interruption, recovery. That is sensemaking in a nutshell. (Weick, 2006, p. 1731)

Sensemaking has been a preoccupation for the field of organisation studies since at least the late 1980s. However, the person that brought it to the mainstream has undoubtedly been Karl Weick, mostly through his papers on the Bhopal (Weick, 1988) and the Mann Gulch (Weick, 1993) disasters and then through his now widely cited book Sensemaking in Organisations (Weick, 1995). In many ways, his account of the phenomenon of sensemaking has become canonical. It has to be 
said, though, that his account of sensemaking has also evolved over time. For example, the account in The Social Psychology of Organising (1979) still had some strong cognitivist undertones that were no longer present in the same way in Sensemaking in Organisations, the latter embracing a process-oriented enactive paradigm more comprehensively (Hernes \& Maitlis, 2012). Nevertheless, although the fundamental ideas of his account of sensemaking remain widely accepted, they have been criticised in a number of significant ways. Specifically, his canonical model has been criticised for its ongoing focus on the deliberative (and even rationalistic) forms of sensemaking (Sandberg \& Tsoukas, 2015), for its episodic treatment of sensemaking (only in moments of breakdown) at the expense of ongoing immanent sensemaking (Colville, Pye, \& Brown, 2016; Patriotta \& Brown, 2011; Sandberg \& Tsoukas, 2015; Thompson, 2011), for its insistence on the retrospective nature of sensemaking processes (Colville et al., 2016; Gephart, Totpal, \& Zhang, 2010), for its lack of attention to the situated, embodied and affective dimension of sensemaking (Cunliffe \& Coupland, 2012; Maitlis, Vogus, \& Lawrence, 2013), for its privileging of presence and closure at the expense of absence and openness (Holt \& Cornelissen, 2014) and, finally, for its mostly anthropocentric, and concomitantly, linguistic orientation, with its focus on accounts, narration, stories, etc. (Berthod \& Müller-Seitz, 2018; Cornelissen, Mantere, \& Vaara, 2014; Hultin \& Mähring, 2016). Of course, there are more, such as its lack of attention to the ordering role of the broader institutional context (Contu \& Willmott, 2003; Weber \& Glynn, 2006), and to the already given epistemic cultures in which sensemaking happens (O'Leary \& Chia, 2007), and more besides. Clearly, there is no way one could address all of these concerns at once. How should one proceed then?

In their recent and extensive review and critique of the sensemaking literature Sandberg and Tsoukas (2015, p. S26) provide some guidance on where to focus. They recommend that further attention needs to be paid to temporality, immanent sensemaking and embodied sensemaking. We would suggest that the lack of attention to immanent and embodied sensemaking relates to a certain privileging of that which can be made present (through human ordering practices), and implies a certain anthropocentrism. Hence, we would suggest that there are at least three intertwined elements that most of these concerns are connected with, and as such need to be considered in any attempt to reimagine sensemaking practices differently. First is the way temporality is understood in the canonical model and also in literature that is more recent, such as, for example, the work of Gephart et al. (2010) and Wiebe (2010). That is, temporality taken either as containers of sense, or as frames for making sense. Second, and related, is what one might call the metaphysics of presence (or, what Derrida (1976) calls logocentrism). That is, privileging as more true or valid that which can be made present - through the ordering processes of sensemaking practices, or made present linguistically, as sensible accounts, narratives or stories, etc. - at the expense of that which is absent and perhaps ineffable. Third, a profound anthropocentrism in which sense is primarily the outcome of human ordering practices, individually or collectively. More specifically, the mostly implicit claim that humans are the original source and primary authors of their sensemaking practices, in some way.

The aim of this paper is to imagine and propose a different understanding of sensemaking that addresses these three aspects - temporality, logocentrism and anthropocentrism - more or less directly. The main thrust of the paper is to develop a notion of sensemaking that is decentred (not simply at the disposal of human subjects) and where sense is always and already given and made simultaneously. Central to this attempt is the idea that our seemingly obvious sensemaking practices, and our accounts of them, are always and already grounded in something more immanent, which does not need to become expressed or articulated to be meaningful (and may indeed be ineffable). What we might call our ongoing dwelling in the flow of life itself (Heidegger, 1962, 1971; Ingold, 2011, 2015). As beings always and already in-the-world, the world already more or less 
makes sense, at least practically (Heidegger, 1962). The flow of life is already its own 'model', its own frame of sense. The flow of life, in all its liveliness, overflows with sense - a sense in which the human is already enmeshed in, that is, affected, or positioned, very specifically. Of course, Weick (2006) might agree with this. He would suggest, however, that our entanglement in the flow of life itself is a 'vast undifferentiated background', which requires humans to 'introduce order, and then selectively single out manageable moments' from it (Weick, 2006, p. 1724). Hence, his summary of sensemaking as constituted by the following logic, 'order, interruption, recovery,' as quoted above. It is this claim that our dwelling in the flow of life is a more or less 'undifferentiated background' that requires the human sense-maker to order, and reorder it in moments of interruption, for meaningful action to take place, which is at the heart of the canonical model of sensemaking. Differently stated, it is the assumption of the need for, and efficacy of, human 'ordering' - and the nature of any such ordering practices, if required - that we want to challenge here by attending to temporality, logocentrism and anthropocentrism. In doing this we will respond to the call of Sandberg and Tsoukas (2015, p. S26) to extend the sensemaking literature, especially in terms of temporality and imminent sensemaking practices.

In reimagining sensemaking, we will draw on a number of authors and intellectual traditions, especially the work of Bergson, Heidegger and Ingold. We will use this work to argue for a different notion of sensemaking that sees the temporality of sensemaking as the interpenetrating and indivisible flow of duration, and the sense-maker as always and already enmeshed in the sociomaterial world in which sense is as much given as it is made. We will then deploy these resources to provide an alternative reading of sense and sensemaking in the case of the Mann Gulch tragedy (Granger, Cochran, Price, Mays, \& Loring, 1949; Maclean, 1992), which was analysed by Weick, and which is seen as one of the canonical accounts in the sensemaking literature.

\section{Sensemaking: temporality, logos and anthropocentrism}

It is beyond the purpose of this paper to undertake a detailed review of the sensemaking literature. This has been done recently by Maitlis and Christianson (2014) and by Sandberg and Tsoukas (2015), both excellently. Based on the critical assessment and recommendations of Sandberg and Tsoukas (2015), as well as some of the other concerns outlined above, we now want to turn in more detail to the three aspects proposed previously - temporality, logocentrism and anthropocentrism. It is our proposition that by attending to these three aspects an entirely different way of imagining sensemaking becomes possible.

\section{Temporality}

Of course, the question of temporality, like sensemaking, has also been an enduring question for organisation studies (Ancona, Goodman, Lawrence, \& Tushman, 2001; Lee \& Liebenau, 1999), especially in terms of organisational change. However, it is the process theorists - drawing on the work of Bergson, Whitehead, Deleuze, etc. - such as Chia (2002), Tsoukas and Chia (2002), Hernes (2014) and Shotter (2005), among others, who insisted on the importance of the constitutive nature of temporality for a process-oriented study of organisational practices, including sensemaking. Undeniably, most organisation studies scholars now accept the distinction between 'clock time' and 'event time' (Orlikowski \& Yates, 2002; Patriotta \& Gruber, 2015), including the importance of temporality as 'lived' - as has been argued for by process theorists. Yet, most of Weick's work and a large part of the literature on sensemaking still treat temporality as divisible and as 'frames' for sensemaking, in spite of its claims to be situated in the process tradition. Process and practiceoriented scholars would insist, drawing on Bergson, that there is no objective 'container' of time 
(or space, for that matter), external to any event or moment, only duration - that is, the internal and indivisible flow of temporality. As Chia summarises:

For Bergson, real universal time is indivisible and has its origin in our consciousness of duration. Bergson insisted that public clock-time is a 'counterfeit' representation of lived experience produced by the conversion of temporal experiences into discrete and measurable instantaneous moments. (Chia, 2002, p. 864; emphasis added)

It is our contention that the debate about retrospective and prospective sensemaking (Gephart et al., 2010; Wiebe, 2010) is premised on such a conversion of duration into discrete moments of time - past, present and future. Where retrospective sensemaking brings the past into the present and prospective sensemaking brings the future into the present, through some relational connection (enacted, for example, as stories or narrative accounts). However, this assumes that the past has passed and that the future is not yet in the present, something most process-oriented scholars would not accept as meaningful (Bergson, 1911; Chia, 2002). Moreover, we would suggest that Weick's (1995, pp. 110-11) central and enduring account of sensemaking is constructed based on such a division of the indivisible flow of time in experience, in terms of past and present. To demonstrate this, we will quote the relevant section from Sensemaking in Organisations here extensively (also noting that this discussion occurs in a chapter called 'The Substance of Sensemaking'):

Sense and meaning require three things: two elements and a relation. ... Frames tend to be past moments of socialization and cues tend to be present moments of experience. If a person can construct a relation between these two moments, meaning is created. This means that the content of sensemaking is to be found in the frames and categories that summarize past experience, in the cues and labels that snare specifics of present experience, and in the ways these two settings of experience are connected. (emphasis added)

As is clear, in his account of sensemaking, frames and categories transform the past into discrete moments by 'summarising' it, and cues and labels turn the present into discrete moments by 'snaring' it. These transformations (of 'summarising' and 'snaring') then allow such moments to become 'connected', to create meaning or sense - and he claims that this is true for all accounts of sensemaking (Weick, 1995, p. 170). Obviously, such 'connection' implies a prior disconnection - in other words, some sort of a division of the flow of experience (the past and the present) into some form of containers (frames, categories, cues and labels) that then need to be reconnected for meaning or sense to become possible. In other words, sense requires these transformations and connections as its necessary conditions - which implies a particular understanding of the divisibility and flow of temporality, as well as the agency of the sense-maker.

One might suggest that this analysis of his account of sensemaking is unfair to Weick, given everything he has done subsequently, and that the work on temporality and sensemaking has moved on. This is partially true; however, although the more recent publications on temporality and sensemaking tends to adopt the 'lived' time view of temporality they nevertheless still accept the canonical account in which time functions as resources (frames) in the sensemaking process - a way of framing and connecting, in very similar ways to Weick's 1995 work. For example, Wiebe (2010) suggests that managers use time as a frame to make sense of the changes that they are experiencing, in what he calls 'temporal sensemaking' - that is, using time frames to configure and reconfigure 'the relationship of past, present, and future' (p. 216). Gephart et al. (2010), in proposing a 'futureoriented' sensemaking model, suggest that 'Future-oriented sensemaking is thus sensemaking that seeks to construct intersubjective meanings, images, and schemes in conversation where these meanings and interpretations create or project images of future objects and phenomena' (p. 285). Again, time is treated as a frame to project meaning into, or connect to, a not yet future. It is this 
view of time either as containers (needing connection) or as frames for making sense that we want to challenge below, using the work of Bergson, Heidegger and Ingold.

\section{Logocentrism}

Weick (1995, p. 18) proposes that 'sensemaking begins with the sense-maker. "How can I know what I think until I see what I say?"' - and this sense-maker is relational and multiple, of course. This formulation is interesting in two senses. First, its anthropocentric nature, which we will return to later, and second, its emphasis on $\log o s$ - that is, the view that sense is grounded in that which can be made sensible (or known to the 'I') by being said (Cooper, 1989; Holt \& Cornelissen, 2014; Sandberg \& Tsoukas, 2015). More specifically, logocentrism 'presumes that inquiry [sensemaking] may arrive at an immediately present, self-identical object of thought or reason' (Garrison, 1999 , p. 352). In the canonical model, sense is that which is ultimately reducible to the articulable, that which can be made sensible to thought or reason by being articulated (Weick, Sutcliffe, \& Obstfeld, 2005). How then can the world be made to be sensible? It can be rendered sensible as 'cause maps' (Weick, 1979), as 'visions or mental models' (Hill \& Levenhagen, 1995), as 'narratives' (Balogun \& Johnson, 2004), as 'accounts' (Maitlis, 2005), as 'interpretations' (Maitlis \& Sonenshein, 2010), as 'connections' (Klein, Moon, \& Hoffman, 2006), as 'shared intersubjective meaning' (Balogun \& Johnson, 2004; Gephart et al., 2010), and so forth. The key point is that behind all these sensemaking or sense-repairing practices is the idea that sense can be made to present itself (mostly in language), at least in principle, if not in practice. As suggested above, this privileges as more true or valid that which can be made present - through the ordering processes of human sensemaking practices, or made present linguistically, as sensible accounts, narratives or stories, etc. - at the expense of that which is absent and perhaps ineffable, a form of logocentrism (Derrida, 1973, p. 99).

To some extent, sensemaking scholars (and the managers they study) treat the world as simply there to be ordered, in our terms, for our purposes - resources on standby for our instrumental projects (Heidegger, 1977; Holt \& Cornelissen, 2014). Sometimes, however, we also need to let go for sense to show itself, in some way. We need to be open to the possibility that what might be most relevant might be irreducible to language, might even be beyond the thinkable (Holt \& Cornelissen, 2014). As Holt and Cornelissen submit, sometimes 'sense lay beyond articulated or skilled understanding, it lay beyond habit and analysis, and yet is still, inevitably, instrumentally gathered as the wellspring out of which new skills [becomes] possible' (2014, p. 536). It is this beyond, or prior to, the articulable, the $\log o s$, that we want to attend to when reimagining sensemaking practices, below. This does not just mean attending to non-cognitive embodied modes of engagement, as suggested by Cunliffe and Coupland (2012), which is undoubtedly important. It is also being open and attuned to the always and already unsaid - the radical otherness of the other that cannot be summarised or snared - that continually disrupts and destabilises our assumed frames, habits, etc. (Derrida, 1973). The assumption of a world that always in some way makes sense - or can be made to make sense - might be a necessary illusion of our modern mind. Sometimes life is also full of non-sense - both magical and tragic, as we will see below.

\section{Anthropocentrism}

One of the most striking, and least challenged, premises of the sensemaking literature is the idea that it is essentially the human actor that 'makes sense', as is clear from Weick's formulation above, but also evident in the vast majority of literature on the subject. Differently stated, it is the assumption that it is the human actors that are the valid and legitimate ground and authors of all 
sense. Now if one were to accept Weick et al.'s (2005, p. 410) claim that 'sensemaking and organization constitute one another', then we also have to acknowledge that human agency is not the only ordering agency being enacted in the flow of life. Indeed, in many cases it is not even the primary ordering agency, as Latour $(1988,1990,2005)$ has shown - the culture/nature divide does not hold. Thus, it is not just the human subjects that engage in meaning-ordering practices, it is a whole host of actors in the relational whole, which we call the happening of daily life. In the web of agentic flows, the human subject orders, for sure, but it is also always and already being ordered or positioned specifically in such ordering (or sensemaking) practices, as has been suggested by Foucault (1982, p. 781). Stated differently, every human attempt at framing is itself always and already enframed, specifically. We might also say that in a certain manner every sensemaking practice is always and already given sense, in some way. Thus, sense is always made and given simultaneously - not only by other human subjects (as has been argued by Cornelissen, Clarke, \& Cienki, 2012; Gioia \& Chittipeddi, 1991; Weick, 2006) but by a whole host of other actors intra-acting (Barad, 2007, p. 139) with the sense-maker(s) in the very act of sensemaking. Sensemaking practices are sociomaterial practices in which a multiplicity of agentic flows are at stake, as Sandberg and Tsoukas (2015) argued, and has been shown by Hultin and Mähring (2016) in hospital emergency departments, by Cornelissen et al. (2014) in the case of the Stockwell shooting tragedy, and by Berthod and Müller-Seitz (2018) in the case of the KLM flight AF 447 disaster.

Using these three aspects as our guide, we want to put forward a set of ideas, drawing on the work of Bergson, Heidegger and Ingold, among others, to argue for an entirely different way of seeing sensemaking. One that is decentred and where sense is given and made simultaneously. A view in which the interpenetrating flow of temporality is taken seriously, and in which many different agencies mesh to constitute the conditions of possibility for sense to remain indivisible and co-original with all action. Specifically, the action of all sociomaterial actors, acting on the actions of others, action upon action, as it flows in the happening of life.

\section{The Flow of Life Along Lines: On the Making of Sense in Sensemaking Practices}

The lines of the meshwork are not connectors. They are the paths along which life is lived. (Ingold, 2009, p. 38; emphasis added)

Living is sensemaking in precarious conditions. (Thompson, 2011, p. 118; emphasis added)

As was indicated above, Sandberg and Tsoukas (2015) suggested that closer attention should be paid to temporality in the sensemaking literature. This relates, first, to the debate about retrospective and prospective sensemaking, and especially Weick's claim that all sensemaking is fundamentally retrospective. Equally significant, however, is the question of the way the flow of time (or duration) functions in the making of sense (or the giving of sense, one might say). We have argued above that the problem with the retrospective/prospective debate, and Weick's account of temporality in sensemaking, is that it treats time as bounded temporal entities - variously called the past, the present and the future. The problem for sensemaking, according to Weick, is that the relevant present has become disconnected from the relevant past, rendering the present more or less senseless (or confusing). To be precise, a temporal disruption, of some sort, which needs the human sense-maker to restore such disruption by reconnecting relevant moments of the present with relevant moments of the past, as was done by Dodge in the Mann Gulch case, according to Weick. All of this assumes that the past is past (no longer now present) and the future is not yet present. A view not shared by Bergson, Heidegger, or Ingold - and indeed not by process-oriented scholars in organisation studies. 
Bergson argues that the past is never past - that is, no longer present (Deleuze, 1990, p. 55). For him the past does not need to be 'retrieved' or relocated because it is always and already coexisting in the present. Normally we believe the present has passed when it is replaced by a new present. But how would the new present come about if the old present did not pass at the same time that it was, or is, exactly present? Or, as Bergson (2002, p. 127) states so eloquently: 'The essence of time is that it goes by; time already gone by is the past, and we call the present the instant in which it goes by.' Indeed the real question is how is it possible for them not to be contemporaneous. If we consider the relation between the present and the past carefully we will realise that we can only divide them by imposing arbitrary boundaries (or dislocations), which can then allow us to say that the one present is now past and has been replaced by a new one - as we do with clocks (Latour, 1997). However, Bergson (2002, p. 20) suggests that the past is in fact produced immediately and simultaneously with the present (as a mirror image, one might say). Deleuze (1990, p. 59) summarises it succinctly:

The past and the present do not denote two successive moments, but two elements which coexist: One is the present, which does not cease to pass, and the other is the past, which does not cease to be but through which all presents pass.

This contemporaneity of the past and the present also means that in every present there is the whole of the past - since the past never passes it is all of the past that is contemporaneous with every present. However, it is not just contemporaneous with the present, just sitting there passively, as it were. Bergson (1911) argues that this 'memory itself, with the totality of our past, is continually pressing forward, so as to insert the largest possible part of itself into the present action' (p. 219, emphasis added) In this pressing forward the past (or memory) "moves in its entirety to meet experience, without dividing' (p. 220, emphasis added). We have to take note that for Bergson it is memory itself that is pressing forward to be actualised. The actualisation of memory is not based on the capacity of the sense-maker to summarise past moments and connect them with current experience (using cues). Memory has its own rhythms and its own autonomous existence, according to Bergson (Ansell-Pearson, 2010) - it is not at the bidding of the human sense-maker in the way suggested by Weick. Indeed, Bergson never misses an opportunity to point out that remembering is the past moving toward the present rather than the sense-maker, in the present, calling up or reconnecting to the past somehow. This pressing forward is however driven by, and in service of, the pragmatic needs of the present action. What about the future?

Heidegger (1962, p. 174) suggests that our human way of being is not only to be already in the world, thrown in the midst of it, but also to be always ahead of ourselves. Being human is to not be confined in the 'present', but always and already projected towards the future. Our existence is to be already temporally stretched between birth and death - we are "the "between" which relates birth and death' (Heidegger, 1962, p. 426), and which 'relates them through its own stretchedness as a "movement" of existence' (Hoffman, 2005, p. 327). Within this temporal stretchedness of our being, our future is not a now that is yet to be. This is not the temporality of the already futural sense-maker. When I wake in the morning the day before me is not a blank canvas, stretching out before me; rather, the day ahead already stands out as this or that particular possibilities to be and to act. It is not that I already anticipate the not yet future of the day ahead. Rather, in waking I find myself already projected against this futural horizon of possibilities, irrespective of my anticipation of it or not. This always and already projectedness (our futural way of being) is the fundamental horizon for sensemaking - it cannot be otherwise. Thus, it does not make sense to talk about retrospective and prospective sensemaking. All sensemaking, in the indivisible flow of life, is always and already retrospective (the past inserting itself into the present) and prospective (our already futural projectedness) at the same time, in every attempt at making sense whatsoever. 
Ingold (2011, p. 83) captures this temporal stretchedness of the happening of life, and its ongoing movement, with the notion of the flow of life along lines - indivisible lines with no definitive origin, as such. When Ingold (2011, p. 83) says that life flows along indivisible lines, he is of course not talking about a discrete sequence of doings, or displacements of things (that would be a sequence of points). Rather, the flow of life along a line is more akin to listening to the indivisible flow of a melody or a conversation (Ingold, 2002, p. 238). The flow or movement emerges from the temporal stretchedness - the way sounds or meanings interpenetrate, temporally, along the line of flow. How they are conditioned by prior, or condition subsequent, sounds or utterances. What becomes possible to say next is conditioned by what has already been said, the sense of what the conversation is becoming, who we assume we are when speaking, the 'place' where the conversation is happening, and so forth. All of these lines of flow mesh together - what Ingold (2011, p. 63) calls the meshwork - to condition the ongoing flow and unfolding of the conversation, exactly as a conversation, rather than a sequence of interacting utterances. An indivisible line rather than a sequence of points. Of course, one can say or do anything at any time, more or less randomly, but this will be at the expense of the coherence and continuity of the ongoing flow of the conversation or life, which is essential for life to be exactly that, be it work life, or family life, etc.

We as sense-makers are not just temporally enacted beings (already stretched from birth to death); we are also very specifically enacted or positioned in the meshwork of life happening always and already thrown (Geworfenheit) into the world (Heidegger, 1962, p. 174) - that is, always and already enmeshed in the sociomaterial meshwork of lines along which life flows (Ingold, 2015). In the meshwork, the indivisible flow of agency is 'a mode of action which does not act directly and immediately on others. Instead, it acts upon their actions: an action upon an action, on existing actions or on those which may arise in the present or the future' (Foucault, 1982, pp. 788-9; emphasis added). Importantly, this action upon possible actions is not exclusively human, but includes the totality of sociomaterial actors implicated in the flow of any action, as it flows (Barad, 2007; Carlile, Nicolini, \& Langley, 2013; Foucault, 1977; Orlikowski, 2007). The key point is that this sociomaterial meshwork acts, mostly implicitly, as an ongoing horizon of conditionality and sensibility - and not an undifferentiated and mostly equivocal background, as suggested by Weick (2006). As beings enmeshed in the meshwork - already embodied and situated - the lines of flow provide the sense-makers with their field of plausible actions, immediately. They function as a background of implicit solicitations or sociomaterial interpellations - making some actions seem more obvious, more appropriate, more meaningful, than others. As beings, always and already enmeshed in the flow of life (Heidegger, 1962, p. 174), these solicitations appear to us, or make sense to us, not as objects/things, nor as scenes for action, to be made sense of, but as particular meaningful possibilities for action, to be responded to, immediately. Specifically, they appear as a pervasive intentional arc (Merleau-Ponty, 2002, p. 157) continuously and implicitly soliciting and orienting us in the flow of life.

Human beings enmeshed in the meshwork are always and already more or less attuned to the agentic possibilities available to them in their always and already 'there-ness' (Heidegger, 1962). This 'there-ness', of Dasein's being enmeshed, however, 'never signifies a position in space, but signifies rather the leeway of the range of that equipmental whole with which it [Dasein] is most closely concerned' (Heidegger, 1962, p. 420). Furthermore, this 'already-having-found-oneselfthere-ness' or attunement (Befindlichkeit) is disclosed to us through mood (a Stimmung) (Smith, 1981, p. 213). For Heidegger, this being in a mood is absolutely not a feeling, in the sense of a private inner psychological state (Heidegger, 1962, p. 175). It is rather more like the Aristotelian sense of pathos, a passion of the soul or an affectedness - that is, more like the mood of our time or the mood of the meeting; that is to say, always public, in some sense (Dreyfus, 1991, p. 172). It is something that befalls us, in some way, or something we already find ourselves in, from the start. 
As Guignon (2009) suggests, moods 'color in advance the ways in which things can matter to us - whether they are amenable or irrelevant, attractive or threatening' (p. 196). Indeed, they are the condition of possibility for any aspect of the world to matter to us in any way whatsoever. As Sara Ahmed (2014, p. 14) puts it, eloquently: 'A mood becomes an affective lens, affecting how we are affected.' Being in this or that mood allows for the world to appear in this or that way. In being attuned certain things matter specifically (and others not), certain agentic possibilities appear as relevant and available (and others not), in my specific being-there-ness, or enmeshed-ness. It is important to note that although mood conditions (affects how we are affected) it does not determine the agentic possibilities that show up as relevant and available to us, in our ongoing attunement, in the meshwork of life happening.

Before we move on to consider the question of sensemaking in the Mann Gulch case, let us first take stock of what we have gained from the intellectual traditions outlined above. The work of Bergson and Heidegger has shown that temporality is an indivisible movement in which the past is pushing forward, continually inserting itself into the present, and the future already exists in the present as a horizon of projected possibilities already orienting us to be and to act, specifically. This means that it does not really make sense to talk about retrospective and prospective sensemaking. Moreover, this temporal movement, and our attunement, is not simply at our disposal. As such, it does not make sense to treat sensemaking as if the human subject is the one that can use temporality (or temporal entities) to enact sense as suggested by Weick and by a significant amount of the sensemaking literature. This temporal interpenetration of duration moreover suggests that the flow of life is conditioned, significantly, in terms of what is possible to do, be, and say next. Ingold captures this with his notion of life flowing along an indivisible line, rather than a sequence of points. Not just one line, however; a whole meshwork of lines, each with its own duration and rhythm, enacting (or enmeshing) the sense-maker very specifically - what Heidegger calls our thrownness. Or, as Foucault (1982, pp. 788-9) suggests, a meshwork 'of actions brought to bear upon possible actions' which incites, induces, seduces and makes certain actions easier or more difficult - a meshwork that conditions but does not determine any sensemaking practices. Being enacted as enmeshed in the meshwork entails a certain 'being thereness' that manifests itself as attunement, which is itself disclosed to us through mood. That is, an affective lens, which affects how we are affected, or, what matters in what way and what not, in our specific facticity. In sum: what we have is a picture of a temporally constituted sense-maker, enmeshed in a sociomaterial world, in which sense is as much given as it is made. Finally, we also need to add that in the meshwork the lines of temporal flow are historically contingent (Foucault, 1984, p. 81). By this, we mean that there is nothing essential about them. They are often precarious and fragile. They emerge and disappear, often implicitly, based on seemingly mundane, and unconnected, ongoing flows of action. In this sense, agentic flows are immanent in mundane action, but often transcend such actions as they continually transform the mesh of possible actions, contingently - by acting on the actions of others, implicitly. Let us now turn to the case of the Mann Gulch tragedy.

\section{The Mann Gulch Tragedy: In the words of R. Wagner Dodge}

Below is an account of the Mann Gulch tragedy as described by R. Wagner 'Wag' Dodge in his testimony to the Board of Review. It is taken directly from the transcript of the proceedings of the Board of Review (Granger et al., 1949) - henceforth referred to as MGBR. Only the section of the testimony relevant to Weick's analysis is provided here (pp.117-119).

Dodge: 'We arrived over the fire, which was about 60 acres in size, at 3:10 p.m. Jack Nash called my attention upon sighting the fire in Mann Gulch. I took position in the door of the plane to 


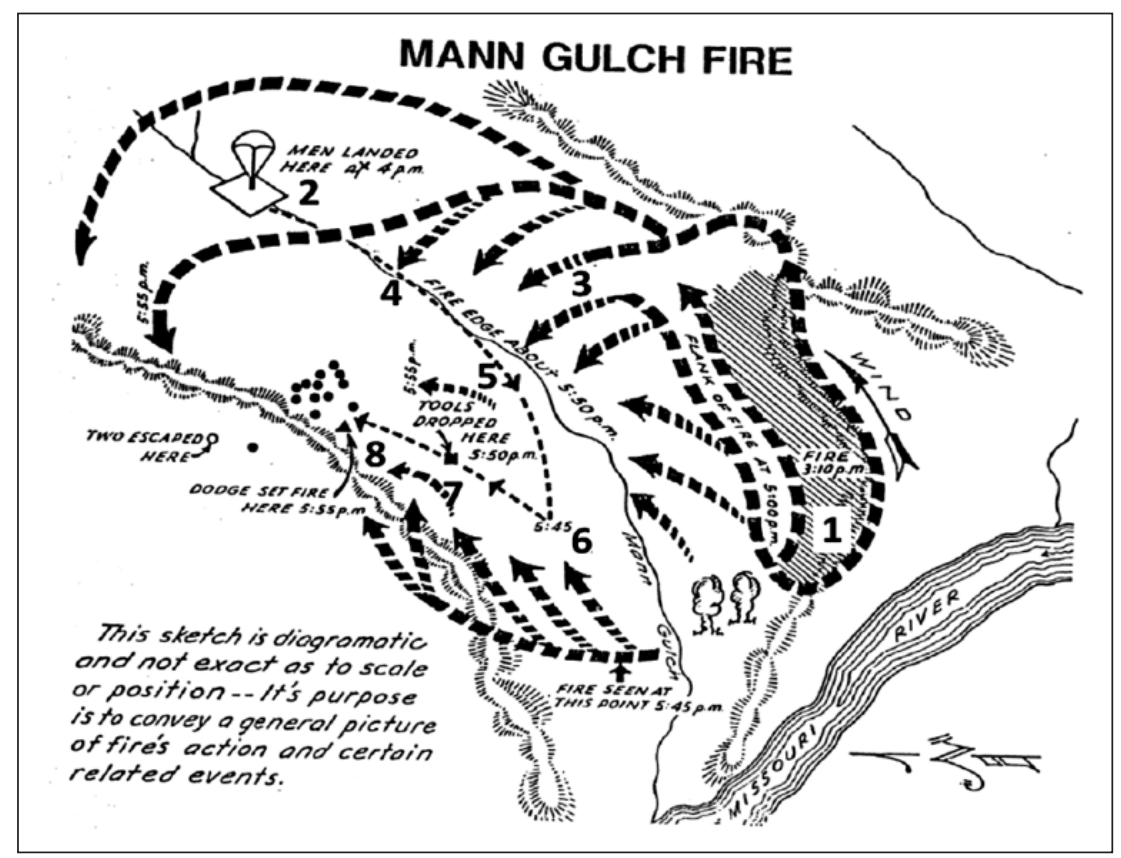

Figure I. Annotated map taken from the Board of Review Report.

observe the terrain and characteristics of the fire. The first tentative jump spot on top of the ridge between Mann Gulch and Meriwether Creek northeast of patrol point was considered suitable because of its position in the path of the fire [point 2 on map, Figure 1]. Another spot was picked in the bottom of the gulch in the vicinity of the head of Mann Gulch. I was concerned over this choice for reasons that if any injuries occurred, it would be almost impossible to get the injured person out. I related this to the spotter, who was Earl Cooley, but I also okayed the spot as suitable to jump to, which was about one-half mile north of the fire. The fire at this time gave indications that its rate of spread would considerably reduce throughout the evening and night [point 1 on map]. It was approximately 3:50 p.m. when I looked at my watch upon landing in the jump area. I had an extremely hard landing, and Rumsey came down the hill and helped me off with my jump gear, and I remained there until the rest of the jumpers were down. Hellman reported to me that all the men were okay that had jumped and we accounted for 13 other jumpers. Merle Stratton did not jump. Our cargo was dropped to us from approximately 5:00 p.m. when all the cargo was retrieved and camp established below the jump area [point 2 on map]. At that time, I could hear someone hollering over on the fire across the canyon [point 3 on map]. I left Hellman with the crew to pick up some subsistence and water before starting down the canyon, and left instructions for him to follow me over to the far side of the canyon with the crew. I contacted Harrison, the prevention guard, up on the head of the fire and brought him back to join our crew, and told Hellman that he should take the crew and return to the northwest side of Mann Gulch and start toward the river grading out of the canyon as he went. Harrison and I returned to our camp area, from where I could see that the fire had started to boil up, and I figured it was necessary to re-join my crew and try and get out of the canyon as soon as possible. I caught up with the crew about 5:40 p.m. [point 4 on the map], and had Hellman stop and see that all the crew was together and to remain on the end of the group. We continued down the canyon for approximately five minutes of travel [point 5 on map] 
before I could see that the fire had crossed Mann Gulch and was coming up the ridge toward us. I then reversed our direction and started to return to the north, up the northwest side of Mann Gulch, climbing as we went [point 6 on map]. After traveling approximately 1,000 feet to 1,500 feet, I instructed the crew to drop all heavy equipment [point 7 on map]. I did not know until later that they had discarded shovels and pulaskis. After returning to approximately above our camp area to the west of Mann Gulch, the fire was too close, in my estimation, to continue farther. At this point, I stopped the crew and explained to those nearest me (at least 8 men) that we would have to burn off a section of the light fuel and get into the inside in order to make it through [point 8 on map]. In my opinion, all my men were still with me or very close and no stampeding was occurring. After setting a clump of bunch grass on fire, I made an attempt to start another, but the match had gone out and upon looking up, I had an area of 100 feet square that was ablaze. I told the men nearest to me that we would wait a few seconds to give it a chance to burn out inside, and then we would cross through the flames into the burned area, where we could make a good stand and our chances of survival were more than even. Upon walking around to the north side of the fire I started as an avenue of escape, I heard someone comment with these words, "To hell with this, I am getting out of here!" and for all my hollering, I could not direct anyone into the burned area. I then walked through the flame towards the head of the fire into the inside and continued to holler at everyone who went by, but all failed to heed my instructions; and within seconds after the last man had passed, the main fire hit the area that I was in. This lasted approximately five minutes, and I was able to sit up within the burned area and look at my watch, which indicated 6:10 p.m. At that time, I heard someone holler to the east of me. Upon investigation, I found Sylvia approximately 100 feet below and 150 or 200 feet to the east of my location. He was badly burned, and I moved him to the shelter of a large rock and made him as comfortable as possible by removing his shoes, clearing an area of rocks, and retrieving his canteen. Then I told him I would start out for some help. Upon reaching the top of the ridge and starting down the other side, I met Sallee and he told me that they had Hellman down below on a rock, and that he was badly burned and Rumsey was okay and was staying with him. I went down with Sallee, and we decided there wasn't anything we could do for Hellman, so we left our water, my coat and some other gear, and Sallee and myself started for help....'

\section{On the Making of Sense in the Mann Gulch Tragedy}

To make sense of the temporal unfolding of the Mann Gulch tragedy, and the manner in which the firefighters were positioned and positioned themselves therein, we need to start with the mood that made it seem appropriate and even necessary to drop fifteen mostly young men into a battle with nature, with potential tragic consequences. Alternatively, as Holt and Cornelissen (2014, p. 534) stated it more succinctly, following Heidegger: 'Why [were] there firefighters, and not nothing?' The post-war period, in which the Mann Gulch tragedy is located, was a very optimistic time, in terms of technological discovery and progress (of modes of transport, medicine, nuclear power and so forth) - many of which emerged from the necessity of war. Indeed, one might suggest that this 'modern' technological mindset, rooted in the idea of war, had become more or less ubiquitous and taken as the obvious answer or comportment towards all problems facing humans. In this mindset, the world (and nature in particular) becomes disclosed and taken as things available for us, for our purposes. In Heidegger's (1977) words, the world is taken as 'standing reserve', on 'standby' for the purposes of the human, who is herself also already enframed (Gestell) - that is, on standby as, for example, smokejumpers for a greater technological and calculative logic, revealed as our modern way of being (Heidegger, 1977, p. 305). Indeed, the name 'firefighter' already carries with it some of this implied meaning, especially with reference to the forest (and nature more generally). 
Thus, what we see are not just a couple of young men, called smokejumpers, jumping out of a plane. What we see is the disclosure and enactment of a particular mood in which these young men are taken as, and take themselves as, fighters risking their lives in defending valuable resources in the name of a greater normative logic - that of technological progress. Differently stated: in this technological mood, they were already disclosed, or made sense of in a particular manner - which framed what they were about to do, and who they were in this doing. They were firefighters, and Mann Gulch was a fire in need of fighting. This mood did not just disclose them, of course, also the world they were already being thrown into - quite literally.

Finding themselves positioned within the meshwork as firefighters, on route to a fire, they already anticipated the job ahead of them. Not because they were 'thinking ahead' (or engaged in prospective sensemaking) but because they were already, in some sense, ahead of themselves, projected into their futural possibilities to be, as firefighters. Thus, as firefighters, en route, already projected, they already imagine immediately - or intuitively as Bergson (1949, p. 6) might suggest - as a concrete, practical and embodied sense the agentic possibilities available to them ahead (Merleau-Ponty, 2002, p. 157). For example, it was immediately clear to them how they might trap the ground fire, and steer it to open ground, by digging their fire line. In many respects the prevailing sense of the firefighters, in the aircraft and after the jump, was one of business-as-usual (Maclean, 1992, pp. 61-2). The fire was burning on the ridge, as a ground fire, in line with the prevailing wind - and 'the fire at this time gave indications that its rate of spread would considerably reduce throughout the evening and night,' according to Dodge. Thus, it would be correct to suggest that they were confident of their positioning, within the flow of the mesh, as able firefighters who could take on the fire confronting them on the ridge.

Business-as-usual does not mean they were reckless or just another group of 15 men in Mann Gulch. As temporal beings (and specifically firefighters) the past was already pressing ahead to push itself into their present. For some of them it might have initially been images or feelings of the loved ones left behind, as they approach the gulch. However, once they left the plane it was their equipment, the fire and their experience of fires that was inserting itself into their present, as well as the possible possibilities ahead of them, already orienting them. In the mesh of the Mann Gulch, which they were about to descend into, there was a whole host of actors already acting on their actions, positioning them specifically. Maclean (1992, p. 47) describes this mesh and being enmeshed beautifully, as they readied to jump:

Even on the first run over the fire, all pertinent pieces of the plane and its universe began to fall into place and become one, preparatory to the jump - the crew, the overhead, the pilot, the airplane, the gulch, the fire in it, and the sky between, all readying themselves for the act.

Attuned to this acting upon their actions the landscape they were descending into already mattered to them in specific ways - already affecting their affectedness, differentially and specifically. For example, when they looked at the grass and the trees, and felt the wind, as they moved, it was not just grass, trees or wind 'in general', rather these actors already mattered to them as 'firefighters' confronting a fire. Specifically, the trees and grass already made sense to them as fuel for the burning fire, the wind as a fan and the creator of potential blow-ups and spot fires, and so forth. As temporally stretched beings, the world around them was already vibrantly alive with sense, but in that very specific 'firefighter' way, and differentially.

It is therefore, we would argue, unhelpful to think of the notion of a 'sudden loss of meaning' (p. 633) or 'collapse' in sensemaking, as suggested by Weick (1993). According to Weick's (1993) analysis there is the 'cosmological disruption' (p. 633) - panic and collapse of organisation and sense - as the fire turns towards, and comes racing at, the smokejumpers. This is followed by 
sensemaking efforts 'to create order and make retrospective sense of what occurs' (p. 635), which allows Dodge to improvise, while his crew, in fear and confusion, 'not sure either what was up or who they were' (p. 636), try to outrun the fire, mostly unsuccessfully. This seems to be a more or less reasonable, and perhaps analytically appropriate account - if one focuses on the human actors and their sensemaking practices, in a moment of assumed collapse of sense. We would, however, suggest that throughout the unfolding tragedy the world made sense to, and of, each of the firefighters, but in a differential way - due to their differential positioning (and attunement) in the flow of action. How it made sense to, and of them, can help us understand why they became enframed as different subjects or participants in the unfolding tragedy. We would suggest that an alternative account that does not depend on a 'cosmological disruption', a 'loss of meaning', a 'collapse of sensemaking' and 'improvisation', can be equally compelling - and maybe more helpful. More specifically, that a temporal disruption and bifurcation, in which sense is lost and then somehow regained through sensemaking practices, is not necessary to understand sense and how it is made. Given our account above, we would suggest that the key question is: why did it seem so obvious and appropriate for Dodge to light the escape fire, and not to his crew, in spite of his attempts to get them to follow him? Similarly, why did it seem equally obvious for the crew to try to outrun the fire, towards the safety of the ridge, and not to Dodge?

The man on the slope was older (33 years old) and more experienced than his crew. Dodge did not imagine the possibility of outrunning the fire, as his injury, the steepness of the slope and the rate of the fire closing in already acted on his actions, affecting him differently, making a different set of actions stand out as appropriate and obvious. As the fire came rushing towards him he did what he describes as simply 'the logical thing to do', to create a burned area to get into for protection (MGBR, p. 123). We would suggest that it was the past pressing into the present, and in the moment, as he was thinking 'with his hands' (Maclean, 1992, p. 103) it simply seemed obvious. No connection with some assumed 'summarised past moment' was necessary (Weick, 1995, p. 111). In responding to the questions of the Board, he does not rationalise this action by relating it to his prior experience (and his skills as a woodsman). No, he replies that it simply seemed like the logical thing to do (Dreyfus, 2004) - it did not require any explanation (and perhaps he could not give one). In contrast, for his crew who were athletic and relatively inexperienced (the youngest being 17 years old), this was not at all the logical thing to do. In the multiplicity of flows of the mesh, they were enacted and affected differently. Dodge, in his testimony, suggested that most of his crew 'had never been on a fire' (MGBR, p. 121) and that he doubts 'if any of them have ever been in any conditions that required any action to save their lives' since they were all 'young fellows' with experience of 'light fire seasons (the past few years) ...' (MGBR, p. 122). Perhaps, for the more athletic young firefighters, who could not judge the progress of the fire, without the action of past experience, it seemed self-evidently obvious that they needed to outpace the fire, to the ridge and safety - which was a mere 200 yards in their minds: 'Well, the ridge looked so close; it looked like we were almost there' (MGBR, p. 78). This is in spite of Dodge's attempts to get them to join him: 'and for all my hollering, I could not direct anyone into the burned area...they didn't seem to pay any attention. That is the part that I didn't understand. They seemed to have something on their minds - all headed in one direction' (MGBR, p. 123). Which was of course the ridge. Why did they not seem to pay attention? Because such 'attention' is an action that assumes a particular positioning, or affectedness. They were already affected differently, disclosing the action of going for the ridge as the sensible thing to do (MGBR, pp.78, 104). According to Sallee's testimony, they were told that 'a fire would slow down or stop when it got to the top of a ridge or just after it broke over the top, it would slow down enough so it wouldn't be dangerous' (MGBR, p. 87). The actions of Dodge did not make sense to them, because they were already positioned differently. The ridge made sense, the escape fire did not. Sense did not collapse, their sense was just already made 
differently - or, stated otherwise: they were positioned and affected differently in the ongoing flow of the incident. As Rumsey suggested in his testimony, of Dodge's action to make the escape fire:

I remember thinking that was a good idea ... I don't remember why, don't know whether I understood. If I had fully realized it I probably would have gone right in. I kept thinking the ridge - if I can make it. On the ridge I will be safe.' (MGBR, p. 104)

Major lines of flow in the Mann Gulch story were the wind, the fire and the slope, among others - acting on the actions of others. The variable wind and turbulence removed one of the smokejumpers, who became ill and returned with the plane; the wind required multiple runs, which meant they were dropped in four short runs (four men at a time). It also scattered their equipment, which in turn scattered the group into finding and collecting equipment. The up-gulch wind, from the river, also created a spot fire, cutting off the downhill escape route to the river (Maclean, 1992, pp. 132-3; Whiteman \& Cooper, 2011). The shifting and variable wind translated, or enacted, a more or less cohesive group into a scattered group, and firefighters into escapees, almost from the moment they left the plane. This is how the up-gulch wind and ultimately the fire acted on their actions - specifically made sense of, or positioned them, we would say. Nevertheless, this is not the sense they had of themselves, until it was too late. Enacted as escapees on a very sharp slope, with an incline of approximately $76 \%$, they were positioned differently. Dodge imagined the possibility of making a fire, as the logical thing to do. His crew imagined the possibility of outrunning the fire for the safety of the ridge, as the logical thing to do, as was suggested above. Had they sensed their positioning as escapees, enacted by the wind, the fire and the incline, they might have acted differently from the start.

There was some evidence that Dodge might have been affected by their positioning, differently, as Sallee suggested. He testified that, early on, after regrouping and eating their meal: 'I think Wag Dodge was worried. I can't remember if he appeared worried, but it seems - I believe he was worried' (MGBR, p. 73). It seems to us that in some way Sallee is trying to articulate something that was ineffable (he appeared worried, seemed worried, was worried). This sense, or prevailing mood, described as 'being worried', might have affected (or positioned) Dodge differently. Perhaps he had already, implicitly, sensed the possibility of them being projected as escapees - that is, started to imagine that an escape might become necessary. Not because he was 'thinking ahead' but because he was affected differently, in the flow of the event - thus, already noticing certain things his crew was not noticing. That is, a particular sense of impending danger pervaded his being-there, even if he could not articulate it. Maybe it was the mood on the ground when they arrived, with the fire 'boiling up'. He never seems to settle in, always on the move - maybe sensing the impossible possibility of a tragedy in the making? We do not know. This is the unsaid of sensemaking, the other that destabilises, even haunts, our accounts. If one reads Maclean's book, meditatively, one can feel it there. That sense that the tragedy was always there, from the start, once they left the plane - almost irrespective of the sensible (or senseless) actions of any human being. It is of course so easy to disregard this unsaid. That is, their 'being there' enacted as a tragedy from the start, it does not make sense - it is essentially senseless (Amiridis, 2018). Be that as it may, our central claim is that by attending to the conditions of possibilities for action, in the unfolding flow of the event and the prevailing moods, it is possible to see how their sense was already given and made in the flow, along lines, and differently. We do not need a sensemaking model of 'order, interruption, recovery' to make sense of how sense was given and made in the mesh of the Mann Gulch tragedy.

Finally, we want to suggest that Weick's (1993) use of the Mann Gulch tragedy as a narrative of organisational collapse and sensemaking is problematic. It is problematic in the way he used the story to support his theory of sensemaking, as has been shown by Basbøll (2010). It is also problematic in the sense that he attributed certain normative judgements to the actors involved. In Weick's 
narrative Dodge is a creative bricoleur who invented a salvation plan on the spot, he continued to 'see a group and to think about its well-being' (p. 638), did not under pressure regress to his most habituated ways of responding (p. 639), was creative under pressure (p. 639) and so forth. His crew, on the other hand, is described as 'stubborn' (p. 636), rebellious, confused (p. 636), their own boss (p. 637), frightened, unthinking (p. 638) and so forth. This is a very particular normatively laden reading of the tragedy. A reading which raises all sorts of questions about how we - and this includes the author of this paper - use the tragedy of others as empirical material for the production of managerial knowledge. In this we need to remain accountable, as Butler (2005) suggests. We also need to be attuned to the ways in which our own sensemaking is always and already conditioned - that is, our sense is already made. This is our scholarly and ethical obligation - something we cannot dispense of in pursuit of theory. Let us now draw some conclusions from our discussion above.

\section{Conclusions: The Decentred Enactment of Sense, or Sense Always and Already in the Making}

We want to conclude this paper by trying to draw out some of the salient points about sensemaking, suggested in our discussion of the Mann Gulch tragedy above. Specifically, to suggest, contra the canonical model of sensemaking, a notion of sensemaking that is decentred, temporally unfolding, always and already affected in its affectedness and in a sense always precarious and incomplete. We also want to return to some of the literature on sensemaking to show how and why our understanding of sensemaking as decentred matters.

\section{Sense is always given and made simultaneously, as it flows}

Sense is always and already, in some sense, made prior to individual or collective sensemaking practices, however we might understand that. Differently stated, every attempt at framing is always and already enframed - and it matters more or less significantly. One way we highlighted this was through the idea of prevailing mood, as a temporally unfolding movement. That is, the notion that subjects are always and already affected, an affectedness that moves - it colours in advance what matters and how it matters (or not). Let us consider the paper by Berthod and Müller-Seitz (2018) on the failure of sensemaking in the case of the AF 447 disaster (see report BEA - France, 2012; Oliver, Calvard, \& Potočnik, 2017). What is really striking about the case is the seemingly nonchalant attitude of the captain (Marc Dubois) throughout the incident. How can one understand it? We would suggest that the crew (and most other crews that fly large aircraft fitted with sophisticated autopiloting systems) were functioning within a particular prevailing technocentric mood in which safety was seen as most effectively secured through technology - that is, through the elimination of human error by isolating many decisions from pilot interference. Thus, the captain was quite rightly expecting the sophisticated systems to be able to deal with what was seemingly a normal situation. This mood is described by Berthod and Müller-Seitz (2018) as 'mindful indifference'. In this mood pilots take themselves to be caretakers of the autopilot system, not as pilots. However, at some point the autopilot disengaged and handed the controls over to the pilots, who were not able to fly the plane based on the information they were getting from the onboard systems. Their sense was now reframed and they were unable to appreciate the change in their situatedness in the unfolding event (even if they were clearly emotionally affected by it). In some sense, their sensemaking practices (or the lack thereof) were already affected, or framed, specifically, in the design of the cockpit systems - as the human error to be excluded, not informed, or enabled. One might say that they were rendered sense-less by the systems they were supposed to make sense of, with tragic consequences. 


\section{The making of sense is always decentred (more-than-human)}

In the meshwork action flows along many lines, human and non-human alike. In the more-thanhuman flow of the meshwork all actors become positioned, differently, which circumscribes the agentic possibilities sensibly available to them in any moment of sensemaking. One might state this differently by suggesting that this more-than-human sense is systemic (decentred), not agentic (centred). For this reason, scholars in the field of situation awareness have argued for a distributed understanding of situation awareness that is more-than-human. For example, in their analysis of the AF 447 disaster Salmon, Walker and Stanton (2016) argues that the first sensemaking failure, in the unfolding tragedy, is between two non-humans (the pitot tubes and the cockpit systems)

whereby the pitot tubes and eventually the cockpit systems lost awareness of the plane's airspeeds. In addition, a key feature of the incident was the inability of the aeroplane's systems to clearly inform the PF [pilot flying] and PNF [pilot not flying] of what was going on .... Given these characteristics of the incident, it is inappropriate to point to a loss of awareness on behalf of the aircrew only. (p. 76)

This analysis contrasts markedly with that of Weick and Roberts' (1993) work on sensemaking on the flight decks of aircraft carriers. In their analysis, they restrict their discussion of heedful interrelating (what they call 'collective mind') to the humans and treat the non-humans as a mere background for heedful human interactions. In discussing the interrelated 'recovery' of an aircraft on a deck they name 15 or 20 people involved in the interactions. However, the interactions of the more than human such as the hook handle, the wands, the groove, etc. are simply assumed in their account - but not in the narrative of the people involved, interestingly. We would suggest that such a view does not appreciate the way in which sensemaking becomes already framed in the flow of the event in which more-than-human actions are profoundly constitutive of the collective sense being made (or not).

\section{The making of sense is ongoing and temporally indivisible}

If sense becomes enacted in the temporal flow of action then (like time) it is ongoing and indivisible movement in which the past is pushing forward, continually inserting itself into the present and the future already exists in the present as a horizon of projected possibilities already orienting us, specifically. Patriotta and Gruber (2015) offers an interesting discussion of how a news organisation deals with two different temporal flows - the planned schedule and breaking news. They argue that these two temporal flows are based on two different temporalities - clock time and event time. They suggest that newsmakers synchronise these two temporalities by drawing on two different sensemaking resources - an expectancy framework (the schedule) and typifications (ways of labelling or categorising breaking events that allow for them to become incorporated within the schedule). Although this is clearly a useful way to think about temporality in organising news production, it treats time and sense as divisible. For example, within the scheduled portion there are also 'unexpected' events continuously challenging the attempt of the schedule to impose itself - a contributor who takes too long to answer a question, a presenter who is too abrupt in summarising the situation, and so forth. And, indeed, news stories interpenetrate temporally, irrespective of the divisions imposed by the schedule. One sees this clearly as the mood of one story frames the next, inserting itself in the present, sometimes in surprising ways. We would suggest that it is exactly because these news makers or presenters are already projected against their futural horizon of possibilities that they expect the 'unexpected' and are able to fold the unexpected into the flow of practice (more or less successfully). The suggestion that breaking news is rendered knowable 
through typifications is useful but we would suggest that the only reason it can be typified in the first place is because the past is already present in such typification practices, which also already anticipate the future. Thus, the separation of clock time (expectation) and event time (the unexpected) is analytically helpful but divides time in ways that do not accord with the lived reality of ongoing news and sensemaking. We would also suggest that there might be many other actors involved that configure the sense of the news as it flows. We will not pursue such a discussion here.

\section{Sense is always irreducible and precarious}

The making present of sense has, as its condition of possibility, also a fundamental absence. It is surprising how little attention the sensemaking scholars give to such constitutive absences. This might be because we tend to focus on sensemaking as deliberative practices that render the present coherent in some way - and indeed this is helpful. However, it is that which continually escapes our perception, is continuously deferred, yet which can disrupt sense at any moment, sometimes tragically, that needs to be acknowledged. We have to acknowledge the senselessness of the world as well - its contingency, fragility and so forth. It seems that sensemaking scholars want the world to always add up. In our case studies, we tend to suggest that if they had just done this, or that, or that, then things would have made sense and the tragedy could have been avoided. It is entirely possible that Dodge and his team were placed in an inescapable position the moment they left the plane - no matter how perfect his or their sensemaking skills (Basbøll, 2010; Maclean, 1992). We just do not know. We have to acknowledge the tragic and precarious nature of human existence if we are to be truthful in our attempts to make sense of sensemaking.

To conclude: it is our contention that we need to move away from what has now become a canonical model of sensemaking. One that is centred on humans, is logocentric, treats temporality as divisible, and sees sense as realisable at any given moment. We believe that if we do we might open up more subtle and perhaps more appropriate understanding of sensemaking 'in the wild', not just for organisational theorists but also for organisational practitioners. Indeed, we would suggest that merely attending to the ways in which their sense is already made (in a decentred manner) would allow organisational actors to become more nuanced in their sensemaking practices.

\section{Funding}

This research received no specific grant from any funding agency in the public, commercial, or not-for-profit sectors.

\section{ORCID iD}

Lucas D. Introna (D) https://orcid.org/0000-0001-6713-4204

\section{References}

Ahmed, S. (2014). Not in the mood. New Formations, 82, 13-28.

Amiridis, K. (2018). The shadow of Sophocles: Tragedy and the ethics of leadership. Business Ethics Quarterly, 28, 15-29.

Ancona, D. G., Goodman, P. S., Lawrence, B. S., \& Tushman, M. L. (2001). Time: A new research lens. Academy of Management Review, 26, 645-663.

Ansell-Pearson, K. (2010). Bergson on Memory. In S. Radstone \& B. Schwarz (Eds.), Memory: Histories, theories, debates (pp. 61-76). New York: Fordham University Press.

Balogan, J., \& Johnson, G. (2004). Organizational restructuring and middle manager sensemaking. Academy of Management Journal, 47, 523-549. 
Barad, K. (2007). Meeting the universe halfway: Quantum physics and the entanglement of matter and meaning. Durham, NC: Duke University Press.

Basbøll, T. (2010). Multiple failures of scholarship: Karl Weick and the Mann Gulch disaster. In N. Butler, P. Carter, \& N. Jackson (Eds.), The leading journal in the field: Destabilizing authority in the social sciences of management (pp. 85-102). London: MayFly.

BEA-France. (2012). Final report on the accident on 1st June 2009 to the Airbus A330-203 registered F-GZCP operated by Air France Flight AF447 Rio de Janeiro-Paris. Retrieved from http://www.bea. aero/docspa/2009/f-cp090601.en/pdf/f-cp090601.en.pdf

Bergson, H. (1911). Matter and memory (N. Paul \& S. Palmer, Trans.). New York: Macmillian.

Bergson, H. (1949). An introduction to metaphysics. Indianapolis, IN: Hackett Publishing.

Bergson, H. (2002). Henri Bergson key writings (K. Ansell-Pearson, J. Mullarkey, \& M. McMahon, Eds.). New York: Continuum.

Berthod, O., \& Müller-Seitz, G. (2018). Making sense in pitch darkness: An exploration of the sociomateriality of sensemaking in crises. Journal of Management Inquiry, 27, 52-68. First published 10 January 2017.

Butler, J. (2005). Giving an account of oneself. New York: Fordham University Press.

Carlile, P. R., Nicolini, D., \& Langley, A. (Eds.) (2013). How matter matters: Objects, artifacts, and materiality in organization studies. Oxford: Oxford University Press.

Chia, R. (2002). Essai: Time, duration and simultaneity: Rethinking process and change in organizational analysis. Organization Studies, 23, 863-868.

Colville, I., Pye, A., \& Brown, A. D. (2016). Sensemaking processes and Weickarious learning. Management Learning, 47, 3-13.

Contu, A., \& Willmott, H. (2003). Re-Embedding situatedness: The importance of power relations in learning theory. Organization Science, 14, 283-296.

Cooper, R. (1989). Modernism, post modernism and organizational analysis 3: The contribution of Jacques Derrida. Organization Studies, 10, 479-502.

Cornelissen, J. P., Clarke, J. S., \& Cienki, A. (2012). Sensegiving in entrepreneurial contexts: The use of metaphors in speech and gesture to gain and sustain support for novel business ventures. International Small Business Journal, 30, 213-241.

Cornelissen, J. P., Mantere, S., \& Vaara, E. (2014). The contraction of meaning: The combined effect of communication, emotions, and materiality on sensemaking in the Stockwell shooting. Journal of Management Studies, 51, 699-736.

Cunliffe, A., \& Coupland, C. (2012). From hero to villain to hero: Making experience sensible through embodied narrative sensemaking. Human Relations, 65, 63-88.

Deleuze, G. (1990). Bergsonism (H. Tomlinson \& B. Habberjam, Trans.) (Reissue edition). New York: Zone Books.

Derrida, J. (1973). Speech and phenomena, and other essays on Husserl's theory of signs. Evanston, IL: Northwestern University Press.

Derrida, J. (1976). Of grammatology. Baltimore, MD: The Johns Hopkins University Press.

Dreyfus, H. L. (1991). Being in the world: Commentary on Heidegger's "Being and Time", Division 1. Cambridge, MA: MIT Press.

Dreyfus, H. L. (2004). A phenomenology of skill acquisition as the basis for a Merleau-Pontian non-representationalist cognitive science. Berkeley, CA: University of California, Department of Philosophy. Retrieved from http://socrates.berkeley.edu/ hdreyfus/pdf/MerleauPontySkillCogSci.pdf

Foucault, M. (1977). Discipline and punish: The birth of the prison. New York: Vintage.

Foucault, M. (1982). The subject and power. Critical Inquiry, 8, 777-795.

Foucault, M. (1984). Nietzsche, genealogy, history. In P. Rabinow (Ed.), The Foucault reader (pp. 87-90). Harmondsworth, UK: Penguin.

Garrison, J. (1999). John Dewey, Jacques Derrida, and the metaphysics of presence. Transactions of the Charles S. Peirce Society, 35(2), 346-372.

Gephart, R., Totpal, C., \& Zhang, Z. (2010). Future-oriented sensemaking: Temporalities and institutional legitimation - Oxford scholarship. In T. Hernes \& S. Maitlis (Eds.), Process, sensemaking, and organizing (pp. 275-312). Oxford: Oxford University Press. 
Gioia, D. A., \& Chittipeddi, K. (1991). Sensemaking and sensegiving in strategic change initiation. Strategic Management Journal, 12, 433-448.

Granger, C. M., Cochran, H. D., Price, J. H., Mays, L., \& Loring, J. M. (1949). Board of Review of Mann Gulch Fire, Helena National Forest, August 5, 1949. Missoula, MT. Retrieved from https://www.nifc. gov/safety/mann_gulch/suggested_reading/Board_of_Review_\%20Sept\%2026_28_1949.pdf

Guignon, C. (2009). The body, bodily feelings, and existential feelings: A Heideggerian perspective. Philosophy, Psychiatry, \& Psychology, 16, 195-199.

Heidegger, M. (1962). Being and time (J. Macquarrie \& E. Robinson, Trans.). Oxford: Blackwell Publishing. Heidegger, M. (1971). Poetry, language, thought (A. Hofstadter, Trans.). New York: Harper \& Row.

Heidegger, M. (1977). The question concerning technology, and other essays (W. Lovitt, Trans.). New York: Harper \& Row.

Hernes, T. (2014). A process theory of organization. Oxford: Oxford University Press.

Hernes, T., \& Maitlis, S. (2012). Process, sensemaking, and organizing (Reprint edition). Oxford: Oxford University Press.

Hill, R. C., \& Levenhagen, M. (1995). Metaphors and mental models: Sensemaking and sensegiving in innovative and entrepreneurial activities. Journal of Management, 21, 1057-1074.

Hoffman, P. (2005). Dasein and "its" time. In H. L. Dreyfus \& M. A. Wrathall (Eds.), A companion to Heidegger (pp. 325-334). Malden, MA: Blackwell Publishing.

Holt, R., \& Cornelissen, J. (2014). Sensemaking revisited. Management Learning, 45, 525-539.

Hultin, L., \& Mähring, M. (2016). How practice makes sense in healthcare operations: Studying sensemaking as performative, material-discursive practice. Human Relations, 70, 566-593.

Ingold, T. (2002). The perception of the environment: Essays on livelihood, dwelling and skill. London: New York: Routledge.

Ingold, T. (2009). Against space: Place, movement, knowledge. In P. W. Kirby (Ed.), Boundless worlds: An anthropological approach to movement (pp. 29-44). New York: Berghahn Books.

Ingold, T. (2011). Being alive: Essays on movement, knowledge and description. London: Routledge.

Ingold, T. (2015). The life of lines. Abingdon, UK: Routledge.

Klein, G., Moon, B., \& Hoffman, R. R. (2006). Making sense of sensemaking 1: Alternative perspectives. IEEE Intelligent Systems, 21(4), 70-73.

Latour, B. (1988). The pasteurization of France. Cambridge, MA: Harvard University Press.

Latour, B. (1990). Technology is society made durable. Sociological Review, 38(S1), 103-131.

Latour, B. (1997). Trains of thoughts: Piaget, formalism and the fifth dimension. Common Knowledge, 6(3), $170-191$.

Latour, B. (2005). Reassembling the social: An introduction to actor-network-theory. Oxford: Oxford University Press.

Lee, H., \& Liebenau, J. (1999). Time in organizational studies: Towards a new research direction. Organization Studies, 20, 1035-1058.

Maclean, N. (1992). Young men and fire. Chicago: University of Chicago Press.

Maitlis, S. (2005). The social processes of organizational sensemaking. Academy of Management Journal, $48,21-49$.

Maitlis, S., \& Christianson, M. (2014). Sensemaking in organizations: Taking stock and moving forward. Academy of Management Annals, 8(1), 57-125.

Maitlis, S., \& Sonenshein, S. (2010). Sensemaking in crisis and change: Inspiration and insights from Weick (1988). Journal of Management Studies, 47, 551-580.

Maitlis, S., Vogus, T. J., \& Lawrence, T. B. (2013). Sensemaking and emotion in organizations. Organizational Psychology Review, 3, 222-247.

Merleau-Ponty, M. (2002). Phenomenology of perception (C. Smith, Trans.). London: Routledge.

O'Leary, M., \& Chia, R. (2007). Epistemes and structures of sensemaking in organizational life. Journal of Management Inquiry, 16, 392-406.

Oliver, N., Calvard, T., \& Potočnik, K. (2017). Cognition, technology, and organizational limits: Lessons from the Air France 447 disaster. Organization Science, 28, 729-743. 
Orlikowski, W. J. (2007). Sociomaterial practices: Exploring technology at work. Organization Studies, 28, $1435-1448$.

Orlikowski, W. J., \& Yates, J. (2002). It's about time: Temporal structuring in organizations. Organization Science, 13, 684-700.

Patriotta, G., \& Brown, A. D. (2011). Sensemaking, metaphors and performance evaluation. Scandinavian Journal of Management, 27, 34-43.

Patriotta, G., \& Gruber, D. A. (2015). Newsmaking and sensemaking: Navigating temporal transitions between planned and unexpected events. Organization Science, 26, 1574-1592.

Salmon, P. M., Walker, G. H., \& Stanton, N. A. (2016). Pilot error versus sociotechnical systems failure: A distributed situation awareness analysis of Air France 447. Theoretical Issues in Ergonomics Science, 17(1), 64-79.

Sandberg, J., \& Tsoukas, H. (2015). Making sense of the sensemaking perspective: Its constituents, limitations, and opportunities for further development. Journal of Organizational Behavior, 36(S1), S6-S32.

Shotter, J. (2005). Understanding process from within: An argument for 'withness'-thinking. Organization Studies, 27, 585-604.

Smith, Q. (1981). On Heidegger's theory of moods. Modern Schoolman, 58, 211-235.

Thompson, E. (2011). Living ways of sense making. Philosophy Today; Charlottesville, 55, 114-123.

Tsoukas, H., \& Chia, R. (2002). On organizational becoming: Rethinking organizational change. Organization Science, 13, 567-582.

Weber, K., \& Glynn, M. A. (2006). Making sense with institutions: Context, thought and action in Karl Weick's theory. Organization Studies, 27, 1639-1660.

Weick, K. E. (1979). The social psychology of organizing (2nd edition). New York: McGraw-Hill Humanities/ Social Sciences/Languages.

Weick, K. E. (1988). Enacted sensemaking in crisis situations. Journal of Management Studies, 25, 305-317.

Weick, K. E. (1993). The collapse of sensemaking in organizations: The Mann Gulch disaster. Administrative Science Quarterly, 38, 628-652.

Weick, K. E. (1995). Sensemaking in organizations. Thousand Oaks, CA: SAGE Publications.

Weick, K. E. (2006). Faith, evidence, and action: Better guesses in an unknowable world. Organization Studies, 27, 1723-1736.

Weick, K. E., \& Roberts, K. H. (1993). Collective mind in organizations: Heedful interrelating on flight decks. Administrative Science Quarterly, 38, 357-381.

Weick, K. E., Sutcliffe, K. M., \& Obstfeld, D. (2005). Organizing and the process of sensemaking. Organization Science, 16, 409-421.

Whiteman, G., \& Cooper, W. H. (2011). Ecological sensemaking. Academy of Management Journal, 54, 889-911.

Wiebe, E. (2010). Temporal sensemaking: Managers' use of time to frame organizational change. In T. Hernes \& S. Maitlis (Eds.), Process, sensemaking, and organizing (pp. 213-241). Oxford: Oxford University Press.

\section{Author biography}

Lucas D. Introna is professor of organisation, technology, and ethics at Lancaster University. His primary research interest is the social study of technology, in particular, theorising the social/technical entanglement, especially with regard to the ethics and politics implicated in such entanglements. He has published on a variety of topics such as sociomateriality, governmentality, ethics, philosophy of technology, information and power, privacy, surveillance, and so forth. 